\title{
Life In Kilis with Its Traditional Urban Fabric and Houses
}

\author{
Funda Yırmıbesoğlu1, Engin E. Eyuboglu1 ${ }^{*}$, Ozhan Ertekın1, \\ Reyhan Genli Yigiter ${ }^{1}$, Neslihan Aydin Yonet ${ }^{2}$ \\ ${ }^{1}$ Urban and Regional Planning Department, Faculty of Architecture, Istanbul Technical University (ITU), \\ Istanbul, Turkey \\ ${ }^{2}$ Department of Architecture, Faculty of Architecture and Design, Bahcesehir University, Istanbul, Turkey \\ Email: *funday@itu.edu.tr
}

Received 21 October 2015; accepted 17 November 2015; published 20 November 2015

Copyright @ 2015 by authors and Scientific Research Publishing Inc.

This work is licensed under the Creative Commons Attribution International License (CC BY).

http://creativecommons.org/licenses/by/4.0/

(c) (i) Open Access

\begin{abstract}
Conserving historic urban environments is currently one of the most universally urgent and challenging cultural heritage conservation issues. Conservation in this paper is seen as a term that covers a wide spectrum of issues that can be classified under three categories: historic urban fabric, traditional Kilis houses and lifestyle concerns. Kilis, which has been a home for many civilizations and cultures throughout history, is an outstanding settlement with its unique historic urban fabric and distinctive house plans. Situated in a transition climate zone, the city also shines for its traditional local cuisine and varied traditional handicrafts. This study aims to give a detailed description of the traditional urban fabric, streets, squares, residential plan types including commonly used architectural details, and the traditional materials in Kilis. The study also examines the lifestyle in Kilis with respect to the city's potentialities. The recommendations regarding how to preserve and maintain the historic urban fabric, the traditional Kilis houses, and lifestyle characteristics are presented in the discussion and conclusion part.
\end{abstract}

\section{Keywords}

Kilis, Traditional, Urban, Home, Lifestyle, Conservation, Urban Heritage

\section{Introduction}

Over the past fifty years, the urban conservation challenge has grown critical due to rapid urbanization and the resulting growth and transformation of cities worldwide. The forces of urban growth often destroy the very

\footnotetext{
"Corresponding author.
} 
social, cultural and environmental fabric they were intended to improve (United Nations Organization, 2013; Getty Conservation Institute, 2009).

Conservation starts with determining what to conserve. The "broadened" concept of monument defined in Venice Charter was reconsidered in 1976 by UNESCO with a different approach and as a result, the concept of "cultural property", which comprises all the physical assets relating to cultural heritage, emerged. The concept covers works of art and property which provide tangible data about the works of art, the level of scientific and technological advancements, and social life of various civilizations and which are worthy of protection. Geological sites, flora, wild life zones, water bodies, and historic gardens that are of aesthetic and scientific value are considered to be "natural property".

The concept "Natural and Cultural Heritage" refers to all the movable and immovable assets to be preserved (Dikcinar Sel et al., 2013).

Conserving historic urban environments is currently one of the most universally urgent and challenging cultural heritage conservation issues. Consideration of conservation in development should thus be seen not only in the light of preserving the built and natural environment, but also the fundamental elements of the social environment equally (United Nations Organization, 2013; Getty Conservation Institute, 2009).

Steinberg (1996) argues that due to a good number of local conservation groups and the existence of international cultural organisations, such as the United Nations Educational, Scientific and Cultural Organisation (UNESCO), the International Centre for the Study of the Preservation and Restoration of Cultural Property (ICCROM) and the International Commission on Monuments and Sites (ICOMOS) monuments have at least a "lobby" and are in a somewhat more favourable situation than urban historic sites and residential areas.

As set out in the UNESCO "Recommendation Concerning the Safeguarding and Contemporary Role of Historic Areas" (UNESCO, 1976), and also in various other international instruments, "the conservation of historic towns and urban areas" is understood to mean those steps necessary for the protection, conservation and restoration of such towns and areas as well as their development and harmonious adaptation to contemporary life (ICOMOS, 1987).

Conservation of the urban historic environment implies a shared responsibility in which decision makers, owners, inhabitants, users, and visitors play key roles. Each player has a different and specific role in the management of the historic urban environment (Getty Conservation Institute, 2009).

While considering planning applications in conservation areas and while protecting cultural and natural properties, all practical steps should be taken to prevent any damage to those cultural and natural properties and they should accordingly be made part of modern life, allowing for "new regulations" and even "new structures" necessary for social life without violating the texture of the area.

Especially with regard to "protection and zoning" in conservation sites, the first and foremost prerequisite is "planning" so that a link between social life and the conservation site could be established without sacrificing scientific merit as well. And it is of utmost importance that this planning cater for a "protective zoning plan" and a lifestyle that is "respectful" to and "in harmony" with history and culture.

Regulations to "promote", even "mandate", rather than obstruct the preservation of conservation sites should be considered. The protection of historical heritage should neither be left to individual efforts nor be sacrificed because of indifference.

As a principle of holistic planning, care is given especially to issues such as "silhouette effects" and characteristics of building-density like "landscape continuity" or "harmonious identity" and so on; however, in terms of urban utilization and "function", the same care should also be given to the principle of "preservation-oriented holism" and an understanding of conservation through revitalizing in parallel to the understanding of museology.

The planning of conservation sites requires planning projects that should be prepared as detailed projects and plans which would take the social, cultural and physical dimensions into consideration. It is not probable that the problems concerning conservation sites could be solved by high-scale decisions made in preservation-oriented zoning plans, which need to be based on very detailed research. The preservation of the "conservation sites", which are of great significance, should be managed through the integration of detailed planning projects designed by those units that fall in the lower levels of current legal/bureaucratic hierarchy (Eyuboglu, 1991).

Over the past 50 years many studies, projects, and planning proposals have been made to conserve historic heritage sites in different parts of the world.

Elnokaly and Elseragy (2013) emphasize the importance of conservation implementations in various Islamic cities in their study. These implementations include the rehabilitation and restoration of the Darb al asfar Quarter, 
the rehabilitation and revitalization of the whole ancient Fatimid city, the conservation of Sidi Bou Said, the restoration of Bukhara Old City, and the rehabilitation of Hebron Old Town.

Conservation of historical urban areas within the framework of sustainability principle requires active utilization of the historical structures in a city, planning them in a way that they will satisfy the requirements of today's lifestyle and at the same time conserving their economic and social qualities. Therefore, areas to be conserved should be considered together with the actual dynamics of a city (Lichfield, 1988). Moreover, one of the mostly emphasized issues today in terms of urban conservation is the concept of "holism". Holistic conservation proved effective in the conservation of the cities of Bologna and Verona. Bologna and Verona stand out as two important conservation areas with their dynamism in the historical city centers, sustainable conservation policies interwoven with the social and economic dynamics, and living historical identity (Arisoy, 2014).

Bologna, situated in the Emilia-Romagna region in the north of Italy and also known as "the red city" due to its distinctive structures built by red bricks, hosts the oldest university in Europe. The city, the history of which dates back to the 1000's B.C., was located at an intersection of trade routes during the Celtic and Roman ages and the middle age and has traces of various cultures today. Bologna, one of the best-conserved walled cities of Europe, is a typical example of such cities (Arisoy, 2014).

The historical city center of Bologna was seriously damaged due to bombardments during World War II. As a result of the physical expansion of the city on the periphery areas especially after the war, the historical fabric of Bologna was gradually disrupted and today it has large-scaled collapsed areas from the 1960's.

Urban conservation works in Bologna started in 1969 under the leadership of architect Luigi Cervellati. The main approach of the conservation plan designed by Cervelatti was to consider the historical center as a whole living urban organism rather than as a clump of old buildings and to conserve it as a "unique monument" together with its cultural, physical, and social values. According to Cervelatti, the historical identity of a city cannot be solely defined by architectural monuments which are under first-degree conservation. Instead, the city is one whole monument itself with its whole urban fabric, examples of old and new civil architecture, fabric of streets, public areas, open spaces and the social activities that take place in such spaces. What determines the historical identity of a city is the interrelationship among all urban elements. Cervelatti's plan, which was developed and implemented by using only public resources, was also one of the first large-scale projects funded by the European Union (Arisoy, 2014).

The history of the city of Verona, located in the Veneto region in the north of Italy, dates back to the Roman period. The unique architectural layers, formed in different periods of European history of urbanization and architecture, are signs of the cultural diversity in the city. Verona is located in one of the regions with the most intense economic activity and is one of the best examples of how urban and industrial development can be handled in parallel with conservation.

City-scale conservations in Verona started in the 1970's and today the city is considered to be one of the best examples of holistic conservation. The conservation projects which were implemented in the same periods as those in Bologna have parallels with the projects in Bologna in terms of considering the city as a holistic monument. However, the conservation works in Verona were funded in cooperation with private sector and restoration works were implemented by restoring individual buildings one by one, unlike Bologna. The results of this can be clearly seen when we compare the tourism income of the two cities. In the city center of Verona, tourism is the most dominant line of business, and in this regard it is dissimilar to Bologna. After the city was enlisted in the World Heritage list, in Verona, where conservation works are directed by private sector, investments in restoration and tourism increased and the historical center became an internationally-known brand (Arisoy, 2014).

The Sulukule and Ayvansaray conservation projects conducted in Turkey are two examples of unsuccessful implementations. Significant harm to the Outstanding Universal Value of the inscribed area has already been caused by the redevelopment of Sulukule and demolition in Ayvansaray (UNESCO, 2013). Safranbolu and Beypazarı conservation projects, on the other hand, can be considered among successful conservation projects.

Legal regulations concerning the preservation of urban protected sites in Turkey Preservation of urban fabrics is handled as part of the hierarchy of construction plans within Turkish Planning system. The technical, administrative and financial aspects regarding the preservation and planning of urban conservation areas are explained in detail in the Code of Protection of Cultural and Natural Properties numbered 2863 and dated 21/7/1983, which was referred to in the Construction Law numbered 3194, which defines the general framework of construction planning system.

"Conservation sites", which have survived to our time from prehistoric ages as heritage from various civiliza- 
tions, are cities or ruins of cities reflecting the social, economic, and architectural characteristics of their time; they are places abundant with cultural and identified natural properties which were once part of social life or which witnessed significant historic events and, therefore, they are areas to be preserved.

"Conservation plan" shall mean the plan of a conservation site as defined by the law, of the scale prescribed for a master and implementation development plan comprising the entirety of objectives, tools, strategies, planning decisions, positions, planning notes, explanation reports, drafted in a way to entail strategies on job creation and value addition, principles of conservation, terms and conditions of use, settlement limitations, rehabilitation, areas and projects of renewal, implementation phases and programs, open space systems, pedestrian walkways, vehicle transport, design principles of infrastructure facilities, densities and parcels of land designs, local ownership, participatory area management models on the basis of financial principles of implementation, improving the social and economic structure of households and offices situated in the conservation site on existing maps on the basis of field studies providing archaeological, historical, natural, architectural, demographic, cultural, socioeconomic, ownership and settlement data taking into account surrounding interactive areas with the view of protecting cultural and natural property in line with the sustainability principle.

"Conservation plan" shall mean the plan of a conservation site as defined by the law, of the scale prescribed for a master and implementation development plan comprising the entirety of objectives, tools, strategies, planning decisions, positions, planning notes, explanation reports, drafted in a way to entail strategies on job creation and value addition, principles of conservation, terms and conditions of use, settlement limitations, rehabilitation, areas and projects of renewal, implementation phases and programs, open space systems, pedestrian walkways, vehicle transport, design principles of infrastructure facilities, densities and parcels of land designs, local ownership, participatory area management models on the basis of financial principles of implementation, improving the social and economic structure of households and offices situated in the conservation site on existing maps on the basis of field studies providing archaeological, historical, natural, architectural, demographic, cultural, socioeconomic, ownership and settlement data taking into account surrounding interactive areas with the view of protecting cultural and natural property in line with the sustainability principle.

Moreover, the "Convention Concerning the Protection of the World Cultural and Natural Heritage" and the "Convention for the Protection of the Architectural Heritage of Europe” which were prepared by United Nations Educational, Scientific and Cultural Organization (UNESCO) and which were published in the Official Gazette and put into force on 14.121983, number 17,959 are two internationally binding documents regarding the conservation of urban conservation areas.

With its urban fabric, streets, squares, and houses, Kilis is one of the cities that should be conserved. The city is also outstanding with respect to the nature of its social life and its centuries-old traditions and customs. This study describes the features of Kilis and provides recommendations regarding how to conserve and maintain those features.

\section{General Information about Kilis}

Kilis is located in the Southeast Anatolian Region; the southwest of the Hatay-Maras ravine and the Gaziantep Plateau, along the Syrian border, with a total area of $1428 \mathrm{~km}^{2}$ (TUIK, 2012). Located in the north-west of Mesopotomia, the city is on one of the paths that join Anatolia to other Asian countries. The land in the northern part of the city is high and rugged, but descends in the southern part towards the Syrian border. The soil, which is calcerous-calcerless with heavy clay basalt, is red and brown on the outside. The region's most significant river is the Afrin Stream. The region is rich in water sources thanks to other small-scale watercourses. Having fallen under Byzantine hegemony in 985, the region was taken over by the Ottoman Empire in 1516. Kilis was invaded by the French at the end of World War I. In 1921, getting free from the French occupation, Kilis became a district of Gaziantep; and later in 1995, a city (Southeast Anatolian Guide, 2007) (Kilis view see Figure 1).

Kilis belonged to the Aleppo (Halab) Kingdom in the 1460s BC. It fell under the Hittite influence when the Hittite Empire Era began. Alexander the Great set out from Macedonia in 356 BC. Conquering the Anatolian lands from northwest to southeast, he founded Alexandretta and proceeded through Kilis. With Alexander's death in 323 BC, Kilis and its surroundings fell under the rule of Selefkia, which lasted 227 years. The arrival of the Turks into the region begins in the 8th century. The development of the city with the name of Kilis in the district it is in today started in the 1250s, in the time of Egyptian-Turkish Mameluke dynasty (TUIK, 2012, 2013).

Important information about Kilis can be found in the Book of Travels of Evliya Çelebi. According to the book, Kilis originally had a fortress although the traces of it it cannot be found in the city today. Kilis and Azez 


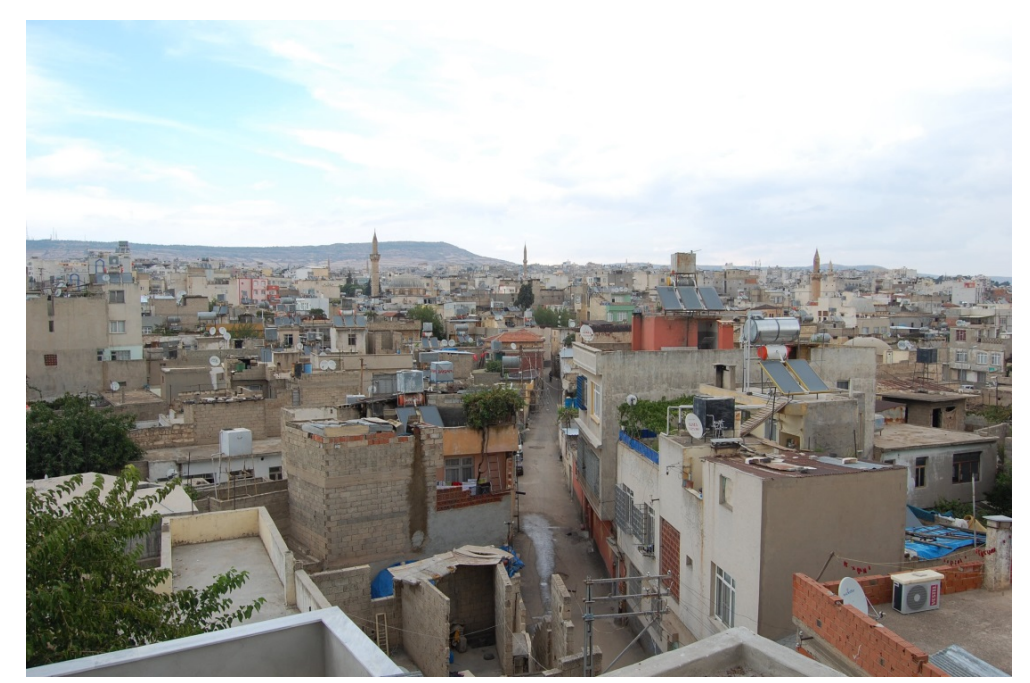

Figure 1. Kilis view, Source: Erguler, 2012.

were provinces belonging to the Sultana. Evliya Celebi also writes that all four sides of the city were surrounded by high walls in the shape of towers and these walls were made of mud brick. The city had 8 gates, none of which were barred. There happened to be no ditches in front of the tower. It is suggested that the city consisted of five quarters, and four thousand six hundred and sixty houses, and had a population of 24,000 people. Considering that this information was recorded in 1648, Kilis appears to be a very ancient and large city (Kilis City Hall, 2013).

Kilis was host to many tribes in history because of its nature and its geography that is conducive to settlement (Babylon, The Hittite, Huri-Mittani, Arameans, Asur, Persia, Macedonia, Rome Byzantine, Seljuq Dynasty, Mamluk Sultanate/Kolemen, and the Ottoman Empire).

Today, Kilis has a population of 124 thousand people, $71 \%$ of which are living in the city and it has an annual population increase below Turkey's average. The net migration rate in 2010-2011 shows that Kilis is one of the migrant-sending cities, with a migration rate of 13.79 per thousand. It has 4 towns, the most populated of which are Merkez and Musabeyli, respectively (TUIK, 2012, 2013) (see Table 1).

The unemployment rate in Kilis in 2010 was $10.1 \%$. The overall unemployment rate in Turkey in the same year was $11.9 \%$, which suggests that Kilis has a lower rate of unemployment compared to the overall unemployment rate in Turkey. In 2011, the number of automobiles per a thousand people was 58 (In Turkey this number was 109) (TUIK, 2012, 2013).

Kilis has a high potential in terms of tourism with its relics from ancient civilizations (Ravanda Tower, tumuli, mosques and masjids, mausoleums, hamams, and fountains), local handicrafts (quilting, weaving, textile, saddlery, packsaddling, shoe making), areas for sightseeing and recreational activities, natural monuments, riches of areas perfect for rural tourism, and local food (Harbalıoglu, Ozel, \& Erkan, 2013, Kilis Gezi Rehberi, 2014). In spite of these values, today the city seems to be lacking sufficient infrastructure, security, accommodation facilities, and transportation services (Yirmibesoglu, 2012).

\section{Traditional Urban Fabric}

The city, where a traditional stone architecture is dominant, has an organic fabric. The city's fabric is formed by narrow streets, stone walls, introverted houses with yards and monumental structures. Houses are separated on the outside by high walls. In Kilis' civil architecture, house plans are usually organized in the east-west direction, parallel to the topography. The reason for this is the climate conditions. In order to block the cold air from the south and the desert, the facades of the structures are mostly built towards the sun. It can be seen that the houses are built close to one another and within the same building blocks as particular structures such as manufacturing, commerce, and cultural structures and that these building blocks have a considerable structural unity (Southeast Anatolian Guide, 2007; Kilis Inventory, 2008; TRC1 House, 2012; Kilis Gezi Rehberi, 2014) (Kilis Streets Figure 2). 

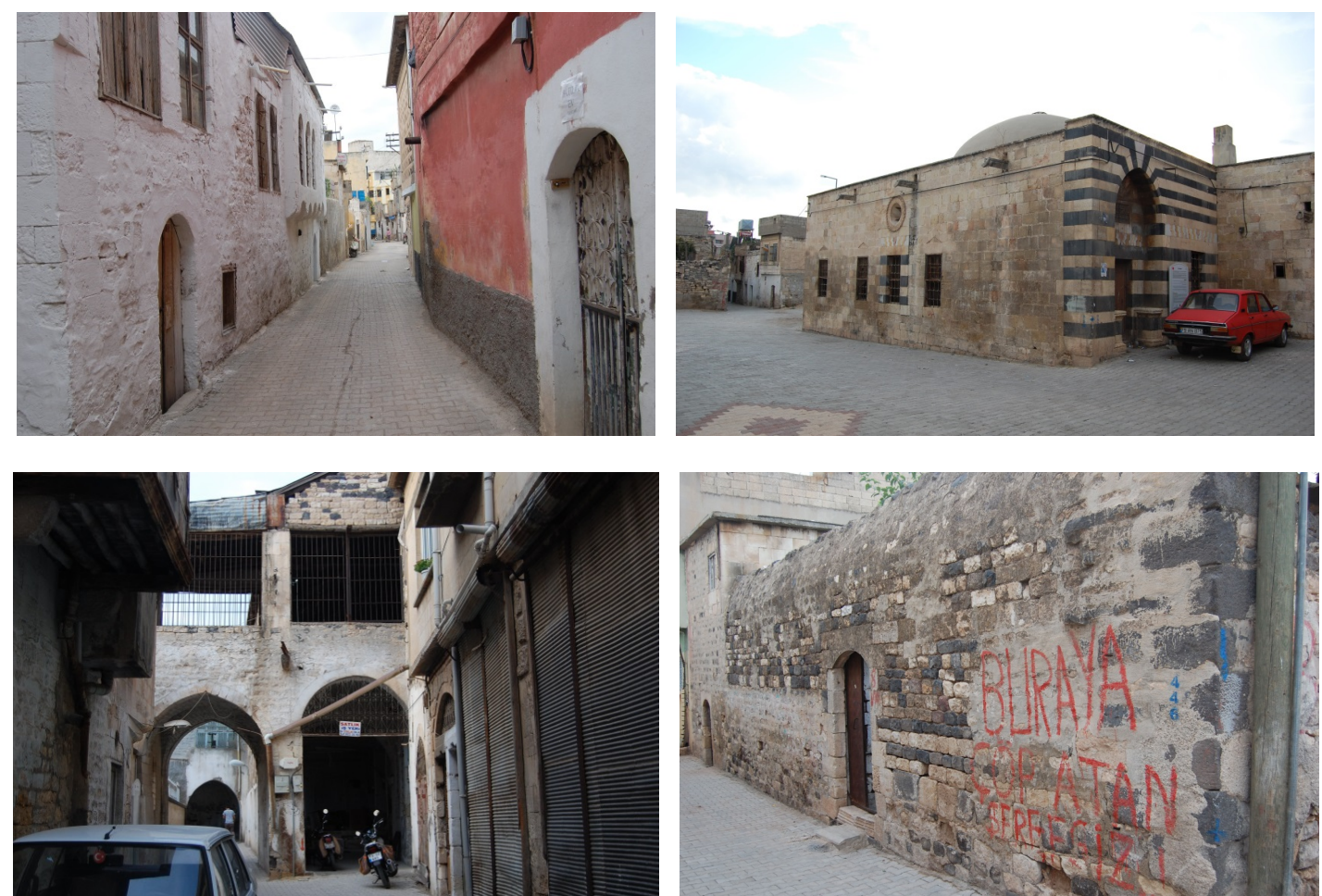

Figure 2. Kilis streets source: Erguler, 2012; Karagul, 2012.

Table 1. Population of Kilis.

\begin{tabular}{cccccccccccc}
\hline Year & Total & Change & $\begin{array}{c}\text { Towns and } \\
\text { villages }\end{array}$ & $\begin{array}{c}\text { Towns and } \\
\text { villages\% }\end{array}$ & $\begin{array}{c}\text { Province and } \\
\text { district } \\
\text { centers }\end{array}$ & $\begin{array}{c}\text { Province and } \\
\text { district } \\
\text { centers } \%\end{array}$ & Male & Male \% & Female & Female \% \\
\hline 2000 & 114.724 & - & 39.739 & $35 \%$ & 74.985 & $65 \%$ & 57.081 & $49.8 \%$ & 57.643 & $50.2 \%$ \\
2007 & 118.457 & $3 \%$ & 36.038 & $30 \%$ & 82.419 & $70 \%$ & 58.489 & $49.4 \%$ & 59.968 & $50.6 \%$ \\
2011 & 124.452 & $1 \%$ & 36.513 & $29 \%$ & 87.939 & $71 \%$ & 62.107 & $49.9 \%$ & 62.345 & $50.1 \%$ \\
\hline
\end{tabular}

Note: Source: TUIK, 2011, 2007, 2000, Census of Population.

The neighborhoods are characterized by narrow streets, dead-end streets or pendentives, which are also called tonos or tunnels (a street with a covered passageway). Due to some house parts built on some fractions of the streets, in summer streets are shadowed, and the houses on top of them are cool.

There are 4 or 5 separate houses on these dead-end streets (Figure 3). Since these dead-end street houses were more valuable in the past, Kilis' prominent families usually preferred to live in houses on dead-end streets, or side streets. The main reason for this was that people didn't prefer their houses to be out in the open in time of war.

Below are typical narrow Kilis streets and a gate to a house (Figure 4).

\subsection{Traditional Kilis House}

Kilis houses bear remarkable similarity to Gaziantep houses. Facades facing streets are completely blind walls. Houses are mostly introverted and are generally one or two-storied houses built with regional yellow, red and black stones. The walls of these structures are made of white or off-yellow stones and archways, door entries, and window peripheries consist of alternatively placed black, white and red stone belts (Southeast Anatolian Guide, 2007; Kilis Inventory, 2008; TRC1 House, 2012). 


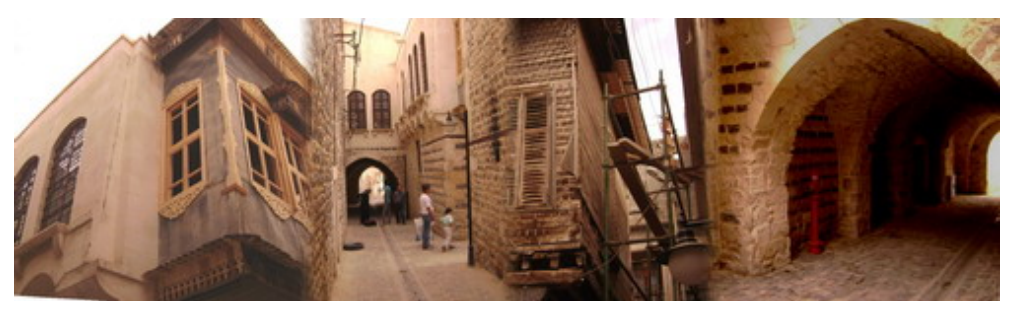

Figure 3. Kilis houses source: Kilis City Hall (2013).
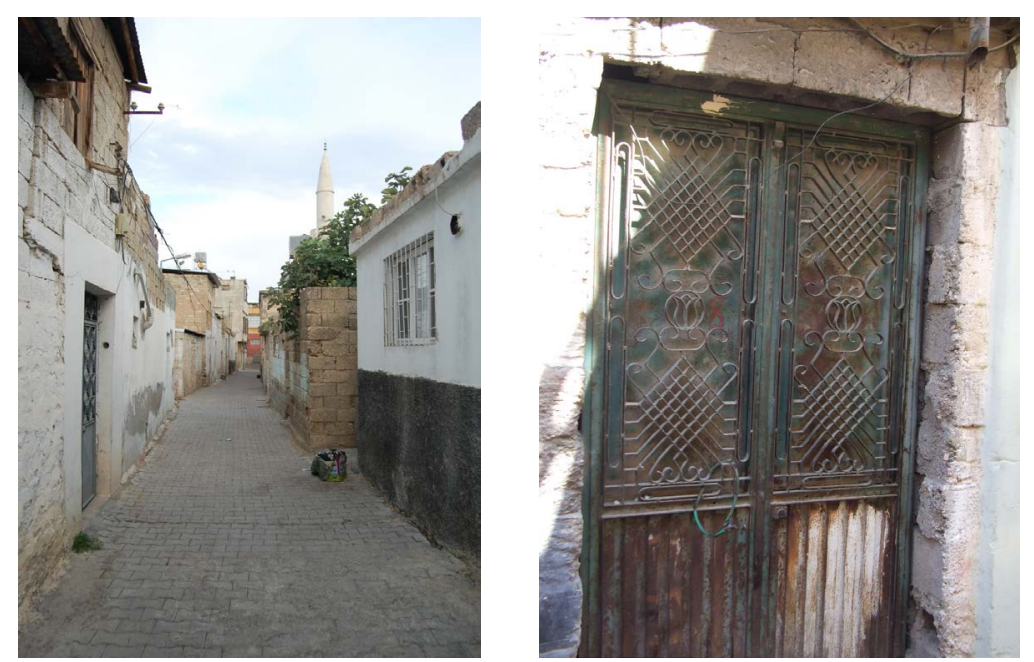

Figure 4. Kilis streets and a gate Source: Erguler, 2012.

Traditional Kilis houses are made of:

stone,

mud-brick and,

leften (an off-white building stone that is extracted from stone pits around Kilis).

Houses consist of:

Rooms,

Havs = havuş (a yard),

A kitchen and,

A cave (a room in the basement used as a cellar and a woodshed). (Southeast Anatolian Guide, 2007; TRC1 House, 2012; Sad1c, 2011).

In the past, unlike today, extended families living in one household were common in Kilis. Therefore, Kilis houses were built to respond to the needs of these families. Although a few, old Kilis houses can still be found in the city today (Figure 5). Those houses have fallen to pieces or are wrecked. Historical houses have been demolished and multi-story buildings were built instead. Although there still are some families living in some of those historical houses, now they are trapped among those multi-story buildings (Yirmibesoglu, 2012).

Various ornamental objects are widely used as front elements in Kilis houses: gargoyles and oriels are some of the known examples (TRC1 House, 2012).

Every old Kilis house had a circle-shaped doorknocker and a big iron "door handle”. Back in the day, the doors of pilgrims coming back from Hajj used to be painted, and on the outside of the doors of newly-weds, people used to draw bride and groom figures with lime powder (Figure 6).

Houses generally have flat (soil) roofs that are colloquially called "dam”, and these houses are closed to the outside and have no windows opening to the outside, but instead windows open to the yard (havs). Around the "havs" are rooms and the kitchen. Havs = Havuş (yard) (Sadıc, 2011).

Fruits and vegetables such as pepper, grapes, fig, and etc., which grow in the area, are laid on the "dam” (roofs) to dry and then made into paste, molasses or sausages.

In the entrance of the house, there's a restroom usually on the left, or sometimes on the right. The houses 


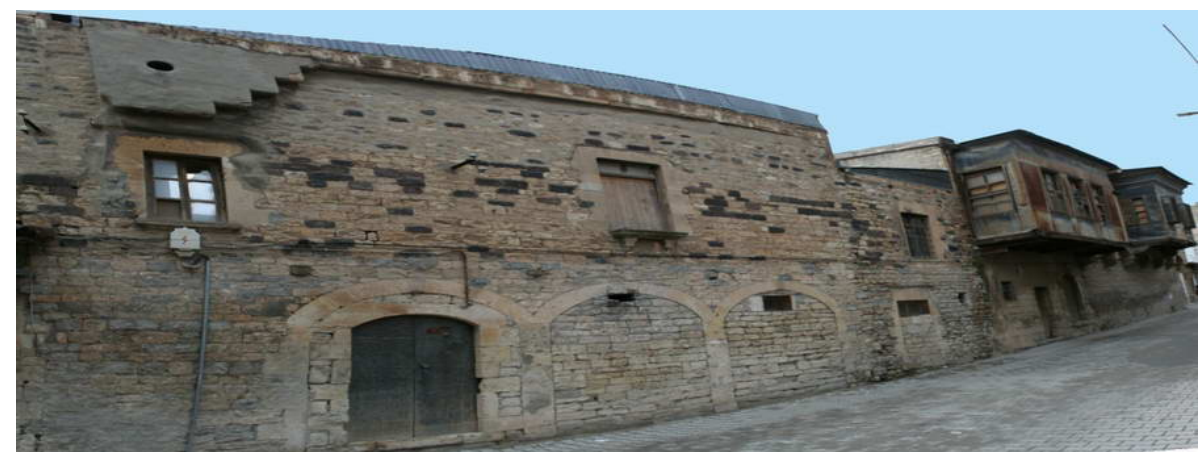

Figure 5. Kilis houses source: (Kilis City Hall, 2013).
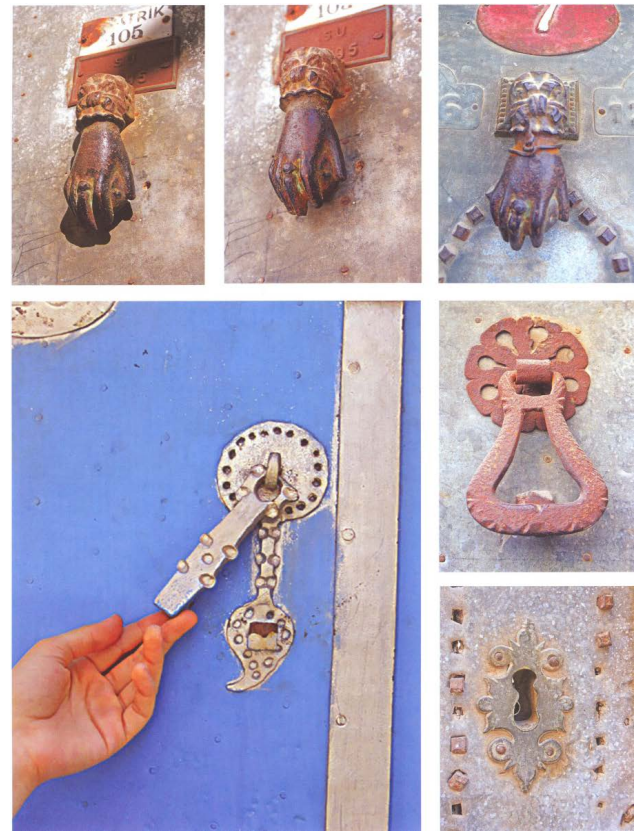

Figure 6. Kilis doors source: Kilis Inventory, 2008.

generally have water wells, which is most of the time the sole source of water. In summer, food and meat are hung into the well inside a handled copper pot, "satıl", in order to keep them from spoiling. Typically, there is an area in the yard (havus) to grow roses, carnations, basil, grape vines, lemons, oranges and apricots (Figure 7).

\subsection{Caves}

Caves are spaces used as cellars and are 4 - 5 degrees cooler than the rest of the house. On hot days, family members spend time in these caves. In some houses, the cave can be reached through another room or through the kitchen via an interior door without going out into the yard (havus). The caves are also used to store yearly stock of "zahre" (groceries such as olives, pickles, cheese, paste, molasses, butter, and etc.) in carra (earthenware jars), and special chests.

If there aren't any other caves in the house, wood and unused goods or goods that need to be stored inside are also kept in the same cave.

\subsection{Rooms}

The rooms of Kilis houses are designed to respond to different needs and purposes, so as to include living rooms, dining rooms, bedrooms, guest rooms and so on. The rooms are accessed either directly from the yard, or via stairs (derec) (Figure 8). 


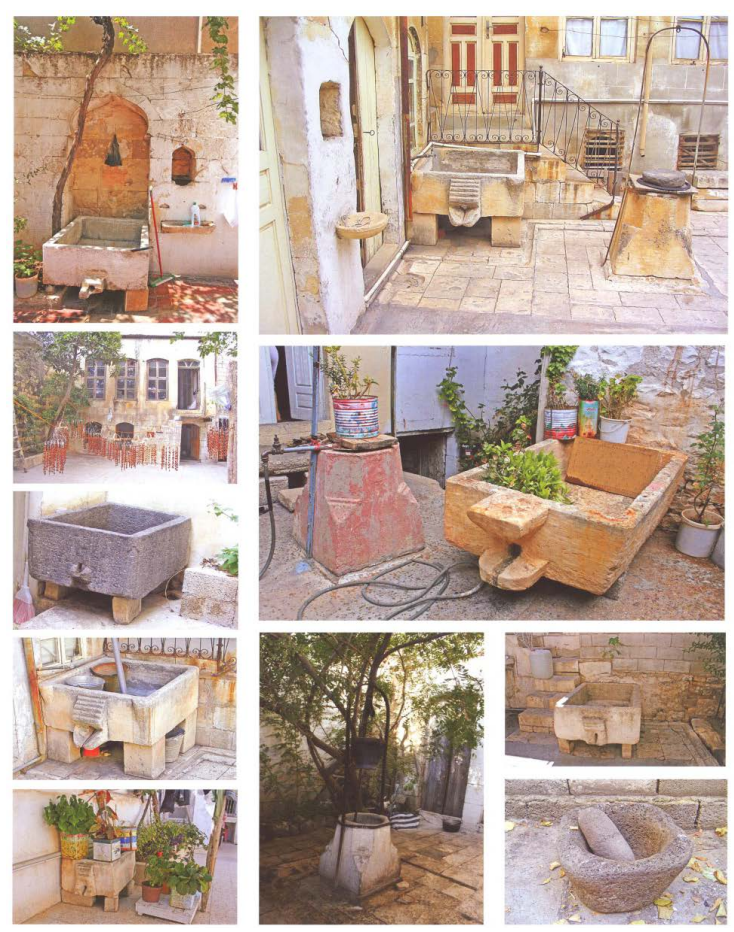

Figure 7. Kilis houses source: Kilis Inventory, 2008.

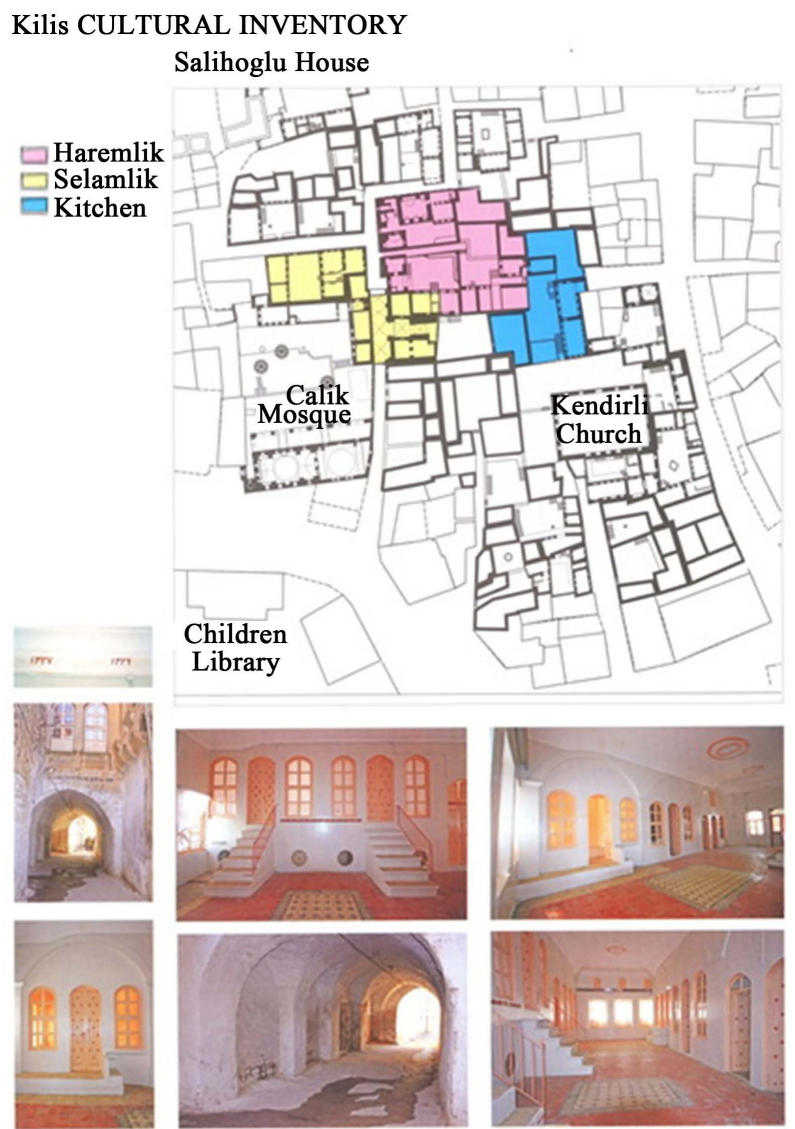

Figure 8. Kilis houses, plan and rooms source: Kilis inventory, 2008. 
Mansions hold a special importance in Kilis. Ahmet Bey Mansion is one of the best examples of the "mansion-type" structures in Kilis (Figure 9).

Built with a regional cut stone, the mansion has two facades facing the street. The yard is entered by an arched door, and on the west side of the yard, there is a water well consisting of only one piece of stone. The structure has two separate entrances called haremlik (for women), and selamlik (for men) (Kilis City Hall, 2013).

In bigger mansions, this separation is usually present. Rooms are constructed facing the south, the west and the north and are called the west room (garp), the east room (sark), the kiblah [south] room (kıble) or the borealis [north] room (poyraz). In winter, people would prefer the rooms facing south, and in summer, north. The room used in winter is 3 - 4 stair steps below the yard (havs). The other rooms are directly entered by the yard (havs), or layer rooms are entered through 4 - 5 steps of stairs (derec) (Figure 10).
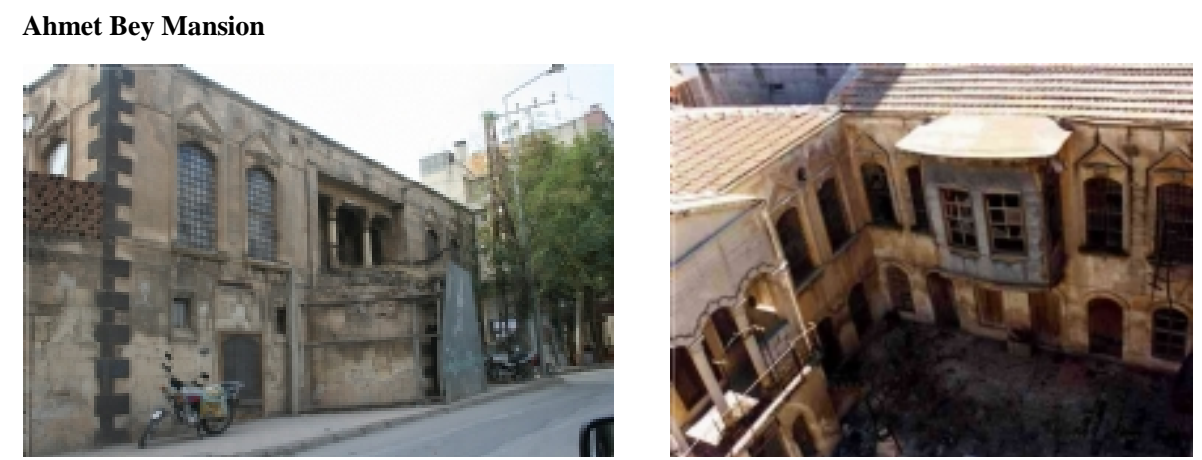

Figure 9. Ahmet bey mansion source: Kilis City Hall (2013).
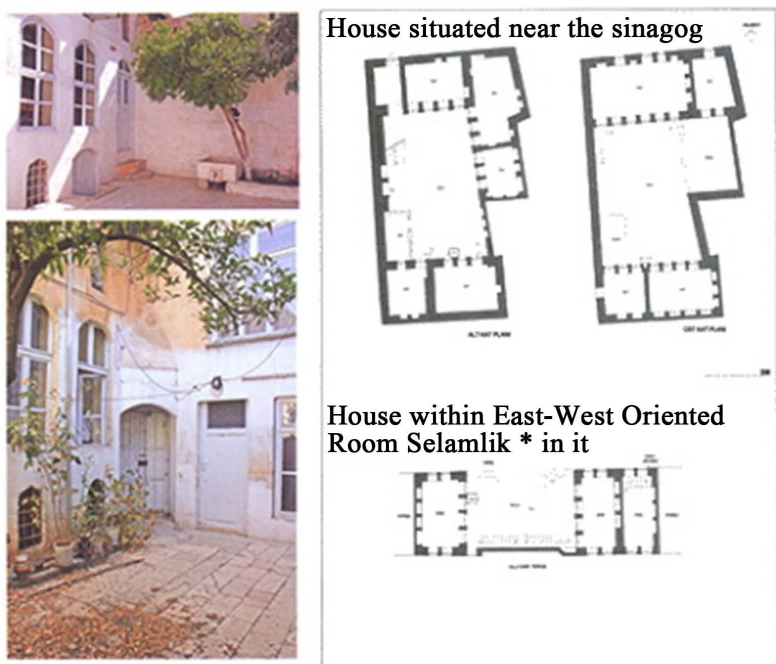

House within East-West Oriented Room Selamlik* in it
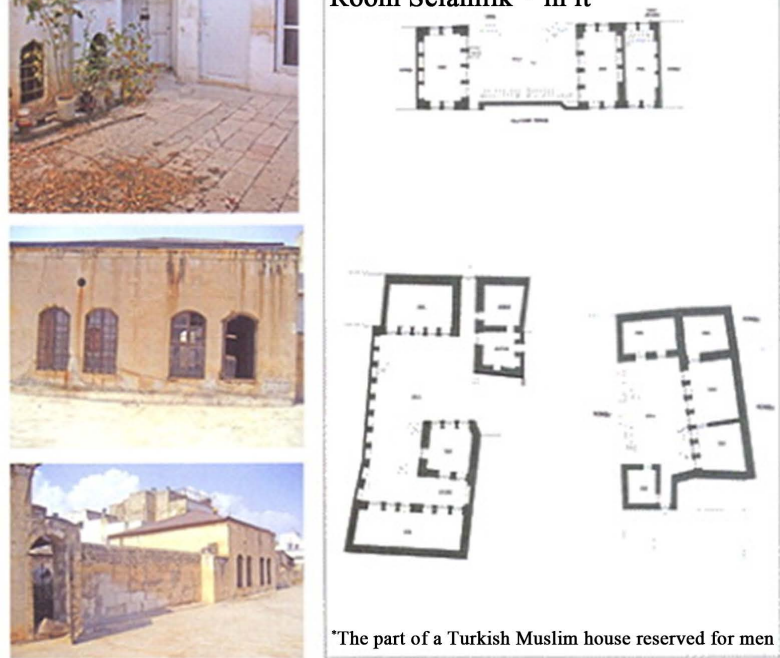

The part of a Turkish Muslim house reserved for men

Figure 10. Kilis houses source: Kilis Inventory, 2008. 
40 - 50 centimeters below the room ceilings, there are bird windows. These windows are usually oval or rectangular, and let sunshine into the room. Rooms consist of 3 - 4 windows (taga), and an entrance door. The building material of these houses and rooms is cut stone.

The rooms are entered through the door threshold (This threshold is generally 2 meters wide, 3 meters long and 60 centimeters deep, and decorated by specially carved marbles.) (Sadıc, 2011).

The doors of the rooms are mostly double-winged wood doors, and have a clip on the back. In the rooms, there are storage closets, built-in cabinets (mahmil) with drawers at the bottom.

Storage closets are used to store mattresses, quilts and pillows covered with an embroidered (kaneviçe) spread. Hung up on the wall are a "the belle of the coffee shop" (a silk wall carpet with figures of women drinking coffee), and an oil lamp. And the drawers are used to store clothes.

Typically, beams are used in the ceilings of the rooms and if need be, some boards are nailed to the beams to make a plaster ceiling beneath them. If clay earth plaster is going to be used over the beams, then the roof is flattened with a stone roller (Figure 11).

The stone roller is rolled on the roof by pulling the handles attached to it. Rainwater gathered on the roofs goes down into the yard (havus) through stone or sheet iron gutters, also known as "çörten" and then goes through "bellea" (the ditch through which supply water in the yard pass), which discharges the waste water of the house and flows outside.
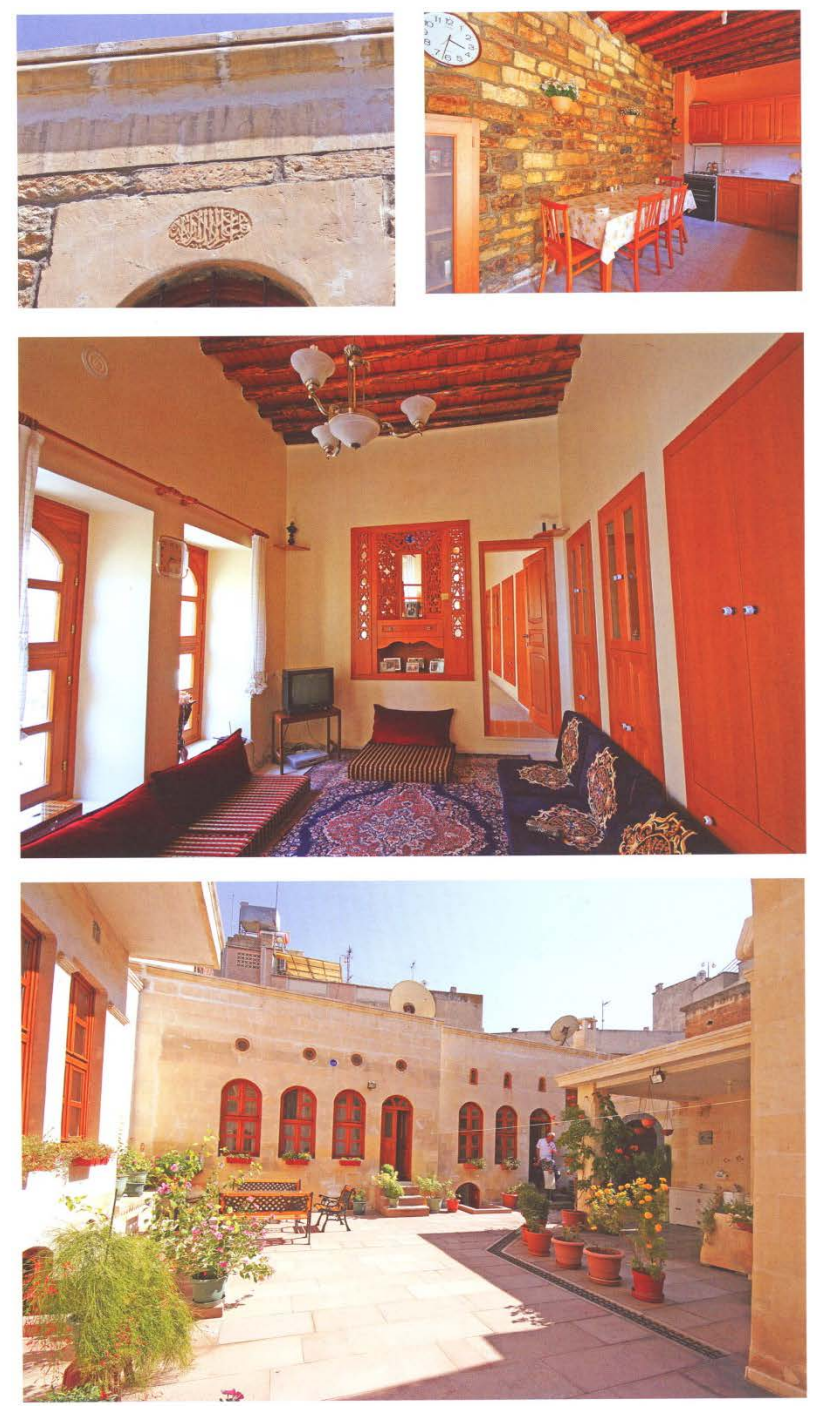

Figure 11. Kilis houses, room and courtyard source: Kilis Inventory, 2008. 
For many years in the past, heating in winter was supplied by a floor furnace, "tandır" (a hole in the floor in the middle of the room that is heated by burning charcoal in a brazier), or a brazier. Later on, stoves were used instead.

The rooms usually had a small hole in the floor, instead of a syphon, to collect the wash water when the room was washed; the wash water was collected in this hole and then emptied with a bowl. Typical furniture in the rooms was chairs, ottomans, couches, carpets, rugs, and floor cushions. The windows of the rooms normally had iron railings.

\subsection{Plan Types}

As is stated in the Kilis Inventory, the plans of the traditional Kilis houses are of seven types. These plan types are shown in Appendix 1. Conservation of these houses along with the plan types, and transmitting them to future generations, gain importance in a holistic conservational approach.

\subsection{Lifestyle in Kilis}

In the old houses, there was also a private room for wealthy and well-to-do people. These rooms had two partitions: "haremlik and selamlik" (for women-for men). The outer door of "selamlik" opened up to the street or the road. In the middle of "selamlik", there was a small yard (havuş) and one or two more rooms around it.

Through the "selamlik" (for men) yard, or another door, haremlik (for women) section can be reached. Food and drinks are served through a small window between "selamlik" and "haremlik". The rooms in "selamlik" are used as guestrooms for guests that come to stay over.

These rooms contain couches, divans, floor cushions, woollen pillows, pans and scoops to roast coffee, large mortar and pestles to beat the roasted coffee, and a brazier. A coffee ewer is always kept boiling on the brazier to keep ready-made coffee hot to serve to guests.

At the time, coffee was brought from Arabia and Sudan. The whole coffee beans were roasted, ground and then mixed with crushed cardamom tree seeds by servants in the rooms. Cardamom is a stimulant for the brain, helps relieve digestive problems and soothes the body. This spice is grown in countries like India, China, Pakistan, and Arabia; and is obtained from these countries (Habbil-hel in Arabic) (Sadic, 2011).

\subsection{Private Room}

In these rooms, teachers from the madrasa and other educated people got together to discuss various agricultural issues about vineyards, vegetable gardens, olive groves, and crops that were locally grown in the villages and farms. During these get-togethers science, literature, and religion were also common topics of discussion. Moreover, the madrasa teachers taught and lectured on intellectual topics such as traditional Turkish music, philosophy, and logic.

Some of these houses in Kilis are Neşet Efendi Mansion (now used as a Public City Library), Ahmet Bey Mansion, Ottoman Daldaban's house in Sihlar District, and the Şeyh Efendi dervish lodge in Bölük district.

The kitchen is in the east of the yard and has a door and a window. In one part of the kitchen, there is a stove with 3 or 4 burners and an extractor hood (puhar) on top.

According to what old timers report, the extractor hood (puhar) was cleaned as follows: Poultry animals such as chickens, turkeys, or roosters were hung down the chimney by their feet and with the fluttering of their wings, the chimney got cleaned (Sadic, 2011).

\subsection{Kitchen}

After the completion of the cleaning process, the poultry was slaughtered and cooked for the household.

Since bread was baked at home in the past, there was a bread tandoor embedded in the wall inside the yard or the kitchen.

In one part of the kitchen, there was an ashpit; ashes taken from the stove were put into this pit. Then, water would be added to the ash and the mixture would be rested. This rested "ash-water" would be used to do the laundry and dishes. "Ash-water”, because of its organic and chemical content, has whitening and cleansing effect.

The kitchen contained daily utensils such as: 
A bread cauldron,

A dough basin,

A meat tenderizer,

A water bucket (kaddus), a wooden cupboard for plates and a spoon drawer or rack.

In addition, there was a kitchen cabinet to store breakfast foods. The shutters of the cabinet were perforated; therefore, the food inside the cabinet didn't go bad, having access to air.

Due to the fact that there was not a bathroom in older houses, water was heated outside, and people bathed in the threshold (entrance of the room) of the living room. Most houses built afterwards had bathrooms that could be entered from the kitchen, which made it more convenient; since it was not possible to heat water in the bathroom, the water that was heated in the kitchen was used.

The bathing room was called "hamam" and on the bathing day the bathroom stove was lit to provide hot water. The stove was lit once a week and all family members bathed on the same day. After coming out of the bathroom, it was a tradition to kiss the hands of the elderly (Sadic, 2011).

\section{Discussion and Conclusion}

Historical environments and traditional urban fabric are evidences of past life. These are areas which distinguish cultural and spatial differences. Although at first the concept of conservation meant only the preservation of important structures, it has evolved today to include issues such as distinguishing spatial differences, maintaining historical identity, and the conservation of cities together with the natural environment. Modern conservation approaches comprise of the acts of evaluation, development, utilization, and gaining economical benefits. One of the aims of conservation is to utilize historical heritage by revitalizing it, and thus, giving it a new function.

Today, conservation positions which have been adopted by many countries in accordance with an understanding of holistic conservation share great similarities in terms of selection criteria and auditing. These shared conservation positions can be summarized as follows (Eyuboglu, 1991):

- To provide the completion of the identification and registration processes by experts based on examinations and scientific reports about the values to be preserved,

- To establish state departments and offices for enforcing conservation practices, and to integrate the conservation and planning organizations,

- To broaden the scope of the law to encompass blocks of buildings with their environs and also conservation sites,

- To enact laws to integrate conservation with planning, or to improve the existing laws,

- To provide necessary funds for conservation purposes to central and/or local administrations in order for them to buy, repair, and restore cultural and natural properties,

- To provide legal means and resources for expropriation or forceful purchase of cultural and natural properties based on public force for conservation purposes when necessary,

- To provide coordination between conservation practices and indirectly revenue-generating activities such as tourism,

- To integrate conservation practices with national and regional development policies,

- To encourage the participation of locals in conservation processes.

Bologna and Verona experiences provide certain answers for conservation-related problems in our country today. These experiences stand out as the best proofs especially in terms of how important the concept of holism in conservation approaches (Arisoy, 2014).

In Bologna and Verona, the cities were designed as a spatial whole. Monumental structures, museums, and symbolic structures are doubtlessly indispensable and conservation-worthy components of the image of a city. As pointed out by Luigi Cervellati, "the fabric of a city is the mirror of these structures". The old and new buildings, streets, green spaces, topography, and silhouette of a city are fundamental components of the identity of the city, which determines the symbolic value of these monuments. The holistic perspective primarily highlights the spatial wholeness of a city (Arisoy, 2014).

Moreover, a city is the product of a social and economical unity. A historical city center means more than an open air museum; it is a living part of a city. If there is a city that should be conserved, renovated, enlivened, and developed, the first thing to start with should be the life in that city and this could be ensured through participatory projects and suggestions born out of local considerations and needs. The fundamental understanding of 
this conservation approach is to consider a city as a whole with its ecological values and social structure and economical activities born out of those values (Arisoy, 2014).

Kilis, with its traditional urban fabric, its streets, squares, house plan types, widely used details inside the houses, and traditional material, is one of the Turkish cities undergoing a change. These potentials bring along a distinction in people's lifestyles, too. Customs and traditions that had been cherished for years are the values that make the city of Kilis, its people and their lifestyle unique. Therefore, it is critically important that Kilis's ancient urban fabric, its houses and lifestyle be preserved. This can be ensured in cooperation with residents through guiding them in how to incorporate the structures into contemporary life, supporting them to access financial resources (e.g. getting state credits and benefits), and initiating social projects with them.

It is a recent concern that Kilis might lose its traditional values, as is the case with all of other Turkish cities that has been going through a process of modernization. People's desire to live in more comfortable houses, the emergence of modern housing zones with no distinctive character in Kilis, the enclosure of traditional houses by these new formations, and the loss of historical fabric pave the way for this inevitable consequence. Briefly, residences are facing the threat of abandonment of old values with regard to both the structured environment and social environment.

Below is a general discussion of the urban fabric analyzed within the framework of the study, main elements concerning the Kilis house and Kilis society, and some suggestions as to preserve the present values.

- Kilis possesses a traditional urban fabric consisting of narrow streets, stone walls, introverted houses with yards, and monumental structures; and this fabric has to be preserved. Central and local administration should take every necessary legal, administrative, social and economical precaution, and carry out an effective regional planning process. Central administration has enacted law number 5366 on Renovating, Conserving, and Actively Using Dilapidated and Cultural Immovable Assets and significant conveniences have been provided for potential users. Necessary studies and information on how to use the law should be provided and people's access to the law should be established for the benefit of the public. In order to encourage conservation practices, successful conservation implementations should be rewarded both materially and non-materially and exhibited to the public. Some portion of the expenses private entrepreneurs spend on restoration should be reimbursed as tax refund. Some raw materials necessary for restoration and other operations (such as cement, marbles, timber, and so on) should be donated by manufacturing organizations to those who have difficulty in restoring their buildings.

- It can be seen that Kilis houses are built with regional stones (lef), other types of stones and mudbrick, and that their materials add distinction to the region. It is crucial that comprehensive communal awareness-raising and social union policies be formed in order for this distinction to be appreciated and preserved by everybody. Recently, there has been a considerable amount of increase in media activity concerning the issue. It is especially obvious from the publications and broadcasts on architectural fabric of old cities that the press is highly sensitive about the issue. Mass media and especially the media organs of TRT should give due importance to the issue. The significance of visual-auditory education has become an undeniable fact and therefore, educational programs on conservation and restoration of historical structures and artifacts could be highly beneficial. This way, it could also be possible to raise public awareness of historical environments. In addition to media organs, using posters, and slogans and illustrations printed on the packages of consumer goods, issuing stamps and postcards, and manufacturing toys of historical monuments or structures could be considered to help raise awareness of the issue.

- Kilis houses have various sections such as rooms, yards, kitchens, and caves and that they stand out with varied plan types. In order for these characteristics to be passed onto future generations and not to be lost, the above-mentioned conservation measures, which would motivate public towards conservation, should be taken.

- Kilis houses have a plan scheme which contains flat soil roofs (dam), no outward windows, room doors and windows opening up to the yard, and a self-enclosed, privatized environment. That the yard consists of small vegetable gardens and water wells and that life is built around the yard are of vital importance. Thus, traditional life style should be preserved and maintained along with this plan scheme. What is of utmost importance here is that the residents or users of these houses should be given the technical support to ensure that their modern life needs are met without spoiling the authenticity of the original structure. This technical support, along with the financial support mentioned above, should be provided through civil participation. 
- In the Kilis house, it is seen that the properties of the rooms designate a special and varied kind of lifestyle. The rooms are planned in order to respond to various needs, such as resting, eating, sleeping, and entertaining guests. Furthermore, there is a texture in which mansions are significant, and inside those mansions, there are special rooms called haremlik, and selamlik. This texture should be protected, and handed down to future generations. The users and owners of the houses should be kept in touch in every step of the conservation works and information offices should be established. Decisions regarding revitalizing historical environments through cultural events may contribute positively to the development of the region. Assembly areas and open areas should be built in order to meet the social needs of the local people. Considering the day's conditions and research data, the physical problems in old structures should be eliminated and the structures should be updated to give them a modern function. In order to slowdown the physical deterioration of the structures in conservation areas, a continuous maintenance and repair program should be implemented. Improper use and unnecessary additional structures that would harm the authentic use of the houses should be efficiently prevented. The necessary restoration or other conservation treatments should be carried out by experts through scientific techniques. The infrastructure needs should be satisfied and the water, electricity, gas, and duct systems should be checked for leaks and damage.

- It can be seen that the culinary culture, including local dishes and coffee, which has become one of the most important topics of scientific conventions and talks, is gaining more and more recognition in the region. Another important part of the culture in Kilis is the Turkish bath (hamam), which contributes its own peculiarities to the family life in the region. It is of utmost importance that these peculiarities and values be preserved as part of the local traditional heritage.

- There is a variety of traditional handicrafts in Kilis. Forgotten in most settlements, the production of these handicrafts should be sustained with the help of the cooperation of public and private sectors and resources should be provided to sustain the production of these traditional handicrafts.

In short, Kilis, with its ancient civilization relics, local handicrafts, areas of sightseeing and resorts, natural monuments, traditional urban fabric, houses, people's special lifestyles, local cuisine and so on, is a region with extraordinary characteristics. Kilis deserves every possible precaution in order for these values to be preserved and for the traditional texture not to be lost.

\section{References}

2863 (1983). 2863 Sayili Kultur ve Tabiat Varliklarini Koruma Kanunu.

5366 (2005). 5366 Sayili Yipranan Tarihi ve Kulturel Tasınmaz Varliklarin Yenilenerek Korunmasi ve Yasatılarak Kullanilmasi Hakkinda Kanun.

Arisoy, A. (2014) Butuncul Kentsel Korumada Bologna ve Verona Ornekleri, CEKUL Vakfi. http://www.cekulvakfi.org.tr/makale/butuncul-kentsel-korumada-bologna-ve-verona-ornekleri

Dikcınar Sel, B., Turgut, S., Yakar, H., Akın, O., \& Yazgan, A. (Dikçınar Sel, B., Ed.) (2013). Kentsel ve Cevresel Koruma. T.C. Anadolu Universitesi Yayini No. 2813, Ac1kogretim Fakultesi Yayini No. 1771.

Elnokaly, A., \& Elseragy, A. (2013). Sustainable Heritage Development: Learning from Urban Conservation of Heritage Projects in Non Western Contexts. European Journal of Sustainable Development, 2, 31-54.

Erguler, L. (2012). ITU Sehir ve Bolge Planlamasi, Proje V ve Proje VI Kapsaminda Kilis'e Yapilan Teknik Gezi Fotograflar1.

Eyuboglu, E. (1991). A Methodological Approach on Planning of Urban Conservation Areas, and Kadikoy Yeldeğirmeni Sonservation Area Case. Unpublished Post Graduate Thesis, ITU Institute of Science and Technology, Istanbul. (In Turkish)

Getty Conservation Institute (2009). Historic Urban Environment Conservation Challenges and Priorities for Action Experts Meeting. http://www.getty.edu/conservation/our_projects/field_projects/historic/experts_mtg_mar09.pdf

Guneydoğu Anadolu Rehberi (2007). Gaziantep Ticaret Odası, sf: 182, 203.

Harbalıglu, M., Ozel, G., \& Erkan, B. (2013). Kilis İlinin Kirsal Turizm Potansiyeli ve Sosyo-Ekonomik Kalkinma Acisindan Degerlendirilmesi. Uluslararası Sosyal ve Ekonomik Bilimler Dergisi. International Journal of Social and Economic Sciences, 3, 55-61.

ICOMOS (1987). Charter for the Conservation of Historic Towns and Urban Areas (Washington Charter 1987). Adopted by ICOMOS General Assembly in Washington DC, October 1987. 
Karagul, O. (2012). ITU Sehir ve Bolge Planlamasi. Proje V ve Proje VI Kapsaminda Kilis’e Yapilan Teknik Gezi Fotografları.

Kilis City Hall (2013). İnternet Sitesi. http://www.kilis.bel.tr/

Kilis Gezi Rehberi (2014). Kilis Valiligi İl Kultur ve Turizm Mudurlugu, Yayiın Kurulu: Aldemir A., Ozturk, M.B. www.kiliskulturturizm.gov.tr

Kilis Inventory (2008). Kilis Kultur Envanteri: Kentsel Mimari, Kırsal Mimari, Yazit Eserleri/Sidika Bebekoglu, Mehmet Tektuna, Kilis Valiligi, Ankara, (AB-GAP Bolgesinde Kultur Mirasinin Geliştirilmesi Hibe Programi Kapsaminda Kilis Valiligi'nce basilmistiır).

Lichfield, N. (1988). Economics in Urban Conservation (pp. 361). Cambridge: Cambridge University Press.

Sadıc, A. (2011). Kilis Sokaklari ve Evlerinin Ozellikleri. Kilis Kulturu, Gazete Kilis. http://www.gazetekilis.com/kilis-sokaklari-ve-evlerinin-ozellikleri/

Savascioglu, R. (2008). Historical Kilis Houses, Selçuk Üniversitesi Graduate School Architecture. MSc Thesis, Konya.

Steinberg, F. (1996). Conservation and Rehabilitation of Urban Heritage in Developing Countries. Habitat International, 20, 463-475.

TRC1 Konut (2012). TRC1 Bolgesi Tarihi, Teorik ve Ampirik Konut Degerlendirmesi İpekyolu Kalkinma Ajansı Arastirma Serisi-7, Gaziantep 2012.

TUIK (2000). Turkiye Iİstatistik Kurumu, Nufus Sayimi.

TUIK (2007). Turkiye Istatistik Kurumu, Nufus Sayimi.

TUIK (2011). Turkiye Istatistik Kurumu, Adrese Dayali Nufus Verileri.

TUIK (2012). Secilmis Gostergelerle 2011 Kilis, TUIK Gaziantep Bolge Mudurlugu, Yayin No. 3855.

TUIK (2013). Secilmis Gostergelerle 2013 Kilis, TUIK Gaziantep Bolge Mudurlugu, Yayin No. 4330.

UNESCO (2013). World Heritage 37 COM, Convention Concerning the Protection of the World Cultural and Natural Heritage, Historic Areas of Istanbul (356), 19-23 November 2012.

UNESCO (1976). The General Conference of UNESCO in 1976 of the Warsaw-Nairobi Recommendation, Recommendation Concerning the Safeguarding and Contemporary Role of Historic Areas.

United Nations Organization (2013). http://www.un.org/ga/Istanbul+5/74.pdf

Yirmibesoglu, F. (2012). I.T.U. Sehir ve Bolge Planlaması Bolumu. Proje V ve Proje VI Icin Kilis Kentine Yapılan Teknik Gezi ve Proje Kapsaminda Yapilan Degerlendirmeler, Proje V ve Proje VI yurutucusu Doc. Dr. Funda Yirmibesoglu. 


\section{Appendix 1}

Plan Type P1. Rooms were located in one corner of the yard.

\begin{tabular}{ccc|c|c|}
\hline Site Area & $71 \mathrm{~m}^{2}$ & \multicolumn{2}{c|}{ P1 } & \\
Base Area & $34 \mathrm{~m}^{2}$ & & \\
Building Covered Ratio & 0.47 & & \\
Floor Area & $68 \mathrm{~m}^{2}$ & & \\
Floor Area Ratio & 0.95 & & \\
\hline
\end{tabular}

Plan Type P2. Rooms were located on opposite sides of the yard.

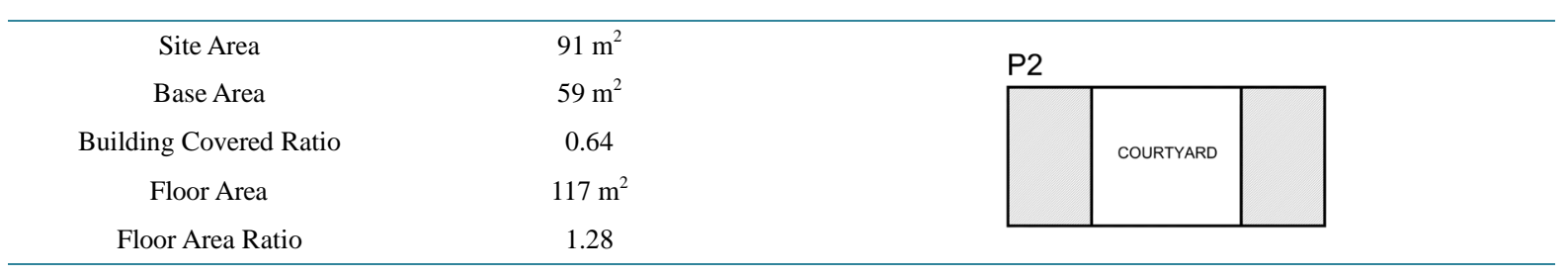

Plan Type P3. Rooms were located on adjacent sides of the yard to form an "L-shape".

\begin{tabular}{cc|c|c|}
\hline Site Area & $175 \mathrm{~m}^{2}$ & \multicolumn{3}{c}{ P3 } & & \\
Base Area & $108 \mathrm{~m}^{2}$ & & \\
Building Covered Ratio & 0.62 & & \\
Floor Area & $216 \mathrm{~m}^{2}$ & \\
Floor Area Ratio & 1.23 & \\
\hline
\end{tabular}

Plan Type P4. Rooms were located in three corners of the yard to form a "U-shape”.

\begin{tabular}{ccc|} 
Site Area & $236 \mathrm{~m}^{2}$ & P4 \\
Base Area & $125 \mathrm{~m}^{2}$ & \\
Building Covered Ratio & 0.53 & \\
Floor Area & $250 \mathrm{~m}^{2}$ & \\
Floor Area Ratio & 1.06 & \\
\hline couRTYARD \\
\hline
\end{tabular}

Plan Type P5. Rooms were located in all four corners of the yard.

\begin{tabular}{ccc}
\hline Site Area & $529 \mathrm{~m}^{2}$ & $341 \mathrm{~m}^{2}$ \\
Base Area & 0.64 & $642 \mathrm{~m}^{2}$ \\
Building Covered Ratio & 1.21 & \\
Floor Area & & \\
Floor Area Ratio &
\end{tabular}

Plan Type P6. Rooms were located on various sides of the yard, as separate pieces.

\begin{tabular}{|c|c|c|c|}
\hline Site Area & $85 \mathrm{~m}^{2}$ & \multirow{3}{*}{$\mathrm{P} 6$} & \\
\hline Base Area & $55 \mathrm{~m}^{2}$ & & \multirow{3}{*}{ COURTYARD } \\
\hline Building Covered Ratio & 0.65 & & \\
\hline Floor Area & $80 \mathrm{~m}^{2}$ & & \\
\hline Floor Area Ratio & 0.94 & & \\
\hline
\end{tabular}


Plan Type P7. Rooms were located around two yards that were connected by a passage.

\begin{tabular}{|c|c|c|c|}
\hline Site Area & $302 \mathrm{~m}^{2}$ & \multicolumn{2}{|l|}{ P7 } \\
\hline Base Area & $162 \mathrm{~m}^{2}$ & \multirow[t]{2}{*}{ COURTYARD } & \\
\hline Building Covered Ratio & 0.54 & & \\
\hline Floor Area & $290 \mathrm{~m}^{2}$ & & COURTYARD \\
\hline Floor Area Ratio & 0.96 & & \\
\hline
\end{tabular}

There is a significant relation between historical interest and house types. Historical Kilis houses reflect the history of society, culture and living style of the period in which they were built. In Kilis architecture, big open areas such as courtyards are frequently seen. The big openings and places, where every kind of need can be met, are clearly noticeable in the architecture of traditional Kilis houses.

The large courtyards in Kilis houses caused the cities to expand on a wide area. The rectangular or square shaped courtyards, with a pool from stone in the middle of Kilis houses, are the crucial points of the Kilis house plan functionally, as well as formally (Savascioglu, 2008). 